\title{
IMPLEMENTASI VIRTUAL TOUR SEDERHANA DALAM PENGENALAN KAMPUS POLITEKNIK PARIWISATA BALI DI MASA PANDEMI COVID-19
}

\author{
M Tanggap Sasmita \\ Program Studi Manajemen Bisnis Perjalanan, Politeknik Pariwisata Bali \\ Jl. Dharmawangsa, Kampial, Nusa Dua, Kabupaten Badung, Bali, Indonesia \\ tanggap.sasmita@ppb.ac.id
}

\begin{abstract}
The Bali Tourism Polytechnic has an annual agenda for campus introduction activities called the Tour De Campus in a series of Basic Professional Attitude Development activities. , but in 2020 tThese activities cannot be carried out directly on campus in 2020 due to pandemic COVID-19. With limited resources and considered important, a Virtual Tour was created to replace these activities. The method used in writing this article is descriptive method from the results of designing activities that are carried out and directly observed. The stages of this descriptive research method are Problem Analysis, Activity Design and Design, and Implementation. Most of the results of the evaluation of the virtual tour activities were satisfied with the activities carried out. This activity can be carried out again in the future by increasing the use of technology to make it more attractive and can be duplicated by schools / campuses / other institutions that have technological limitations.
\end{abstract}

Keywords: virtual tour, campus orientation, Covid-19 pandemi

\begin{abstract}
Abstrak
Politeknik Pariwisata Bali memiliki agenda tahunan kegiatan pengenalan kampus yang di sebut Tour De Campus dalam rangkaian kegiatan Pembinaan Sikap Dasar Profesi, namun di Tahun 2020 kegiatan tersebut tidak dapat dilakukan secara langsung di kampus. Dengan keterbatasan sumber daya dan dianggap penting, maka untuk menggantikan kegiatan tersebut dibuatlah kegiatan Virtual Tour. Metode yang digunakan dalam penulisan artikel ini adalah metode deskriptif dari hasil perancangan kegiatan yang dilaksanakan dan diobservasi secara langsung. Adapun tahapan dari metode penelitian dDeskriptif ini adalah aAnalisa pPermasalahan, dDesain dan pPerancangan kKegiatan, dan iImplementasi. Hasil dari evaluasi kegiatan virtual tour tersebut sebagian besar merasa puas atas kegiatan yang dilaksanakan. Kegiatan ini dapat dilaksanakan kembali dimasa yang akan datang dengan peningkatan penggunaan teknologi agar lebih menarik dan dapat diduplikasi oleh sekolah/kampus/Lelembaga lain yang memiliki keterbatasn teknologi
\end{abstract}

Kata Kunci: virtual tour, pengenalan kampus, pandemi Covid-19 


\section{PENDAHULUAN}

Corona Virus Disease 2019 atau yang kita kenal sebagai Covid-19 yang diawali di Wuhan pada akhir 2019 dan masuk ke Indonesia pada bulan maret 2020 telah membawa perubahan yang cukup berarti pada berbagai sektor, salah satu sektor yang terkena dampaknya adalah sektor Pendidikan. Statistik UNESCO pada 25 Maret 2020 menyebutkan 1.524.648.768 pelajar terdampak oleh Covid-19 atau sekitar 87,1\% dari seluruh total pelajar di dunia. Sejauh ini India dan Tiongkok memiliki jumlah pelajar yang terdampak terbesar, sekitar 270 Juta, dan Indonesia per maret 2020 sebanyak 68.265.787 pelajar terdampak oleh Covid-19. Hal ini memaksakan beberapa pembatasan untuk sekolah dan perguruan tinggi. (UNESCO, 2020). Abidah, dkk (2020) dalam artikelnya menyimpulkan bahwa covid-19 memiliki dampak yang sangat siginifkan dalam dunia pendidikan termasuk dunia pendidikan di Indonesia. Rutinitas pembelajaran secara tradisional yang menekankan pada interkasi antara guru/dosen dan pelajar di dalam maupun di luar ruangan harus berubah kepada distance learning. Dikatakan bahwa model ini sejalan dengan proses pembelajaran masa depan di era revolusi industri 4.0 dan komunitas 5.0 masih memiliki keuntungan dan kerugian. Dari segi kekuatan pembelajaran daring tidak dibatasi oleh ruang dan waktu, terutama sejak pemerintah menerapkan kebijakan untuk melakukan karantina mandiri dan menjaga jarak fisik maupun sosial.

Jika ditelusuri lebih lanjut dampak nyata yang bisa dilihat dari sektor pPendidikan adalah ditutupnya sekolah dan kampus dan mengharuskan siswa dan mahasiswanya untuk belajar dari rumah. Kebijakan belajar di rumah pada institusi pendidikan jelas menyebabkan gangguan besar, seperti pembelajaran siswa, gangguan dalam penilaian, pembatalan penilaian, peluang mendapatkan pekerjaan setelah lulus pendidikan, pembatalan penilaian publik untuk kualifikasi dalam seleksi pekerjaan
(Aji, 2020). Menurut (Aji, (2020) menyatakan bahwa Lembaga penyelenggara pPendidikan harus bersiaga memfasilitasi perubahan apapun menyangkut Pendidikan. Tingkah laku harus menjadi dasar yang baik di tengah pesatnya perkembangan teknologi dan informasi saat ini. Program Pendidikan harus tetap berjalan walaupun dengan media daring harus tetap memperhatikan tujuan dan etika dalam tujuan Pendidikan. https://republika.co.id/berita/qgbaed37 4/virtual-campus-tour-untukmahasiswa-baru-ipb-university

Politeknik Pariwisata Bali (Poltekpar Bali) sebagai institusi Pendidikan di bawah Kementerian Pariwisata juga menerapkan kebijakan untuk pembelajaran jarak jauh termasuk dalam proses pengenalan kampus di Pembinaan Sikap Dasar Profesi yang biasa dilakukan dengan cara offline atau mahasiswa datang langsung ke kampus (Surat keterangan PSDP Online) harus dilaksanakan secara daring.

Kegiatan pengenalan kehidupan kampus secara virtual bukanlah hal yang baru. Beberapa artikel jurnal yang menulis terkait program pengenal kampus dengan metode virtual tour diantaranya di Universitas Kristen Satya Wacana (UKSW) di Salatiga, Jawa Tengah (Rizal, 2018). UKSW memiliki luas kampus $93.580 \quad \mathrm{~m} 2$. Berdasarkan penelitian sebelumnya disampaikan bahwa terdapat kesulitan bagi mahasiswa untuk mengenali lokasi Gedung perkulihan dan mengenali wilayah kampus pada awal masa perkuliahan. Maka dalam penelitian tersebut dirancang virtual tour panorama 360 sebagai media informasi kampus I UKSW dan diaplikasikan pada website universitas.

Kegiatan sejenis dilakukan di Universitas Narotama dalam artikel yang ditulis Oleh Achamd dkk (Achmad. 2016) dalam Artikel mereka yang berjudul Implementasi Sitem Virtual Tour Berbasis E-panorama untuk pengenalan Kampus Universitas Narotama Surabaya. 
Adapun tujuan pembuatan vitual tour berbasis e-panorma pada Univesitas Narotama Surabaya memiliki tujuan dan manfaat yaitu membuat tampilan dalam bentuk gambar panorama yang berisikan pengenalan terhap beberapa lingkungan dan ruang perkuliahan di Universitas Narotama Surabaya sehingga dapat menghasilkan informasi terhadap banyak masyarakat luas dan juga berguna untuk bidang branding dan marketing.

Penelitian lain dilakukan oleh Pandu (2016) dengan judul Aplikasi Pengenalan Kampus Berbasis Web dengan menggunakan teknologi Virtual Tour Studi Kasus Kampus III Universitas Sanatha Dharma). Dikatakan bahwa Universitas Sanatha Dharma sudah memiliki website namun hanya berupa gambar dan teks, tidak ada rute yang dapat menunujukan kondisi fasilitas yang ada. Para mahasiswa barupun meskipun sudah diberikan pengenalan kampus namun masih banyak yang belum mengetahui beberapa fasilitas yang ada. Kemudian peneliti mengembangkan aplikasi dengan menggunakan konsep basis data multimedia dan menggunakan pemrograman berbais web JSP serta DBMS Oracle, dengan pengguna calon mahaiswa baru, mahasiswa baru dan diuji mendapatkan komentar bahwa aplikasinya efisien, efektif, dan easy of use dan membantu para pengguna dalam mengetahui lokasi fasilitas yang ingin mereka ketahui.

Berdasarkan pemaparan latar belakang $\mathrm{di}$ atas diketahui bahwa pelaksanaan kegiatan virtual tour untuk kegiatan pengenalan bukanlah hal yang baru, namun dengan adanya pandemic Covid-19 maka kegiatan virtual tour menjadi lebih viral karena adanya pembatasan kegiatan pertemuan sehingga menggunakan media virtual tour untuk kegiatan pengenalan kampusnya. Termasuk Poltekpar Bali yang baru melaksanakan kegiatan virtual tour dalam kegiatan Pengenalan Kampusnya bagi mahasiswa baru yang pada tahun-tahun sebelumnya dilaksanakan dengan pertemuan massal di Kampus. Dari tiga penelitian di atas dilakukan oleh peneliti dengan latar belakang Teknik informatika dan komputer, namun Politekpar Bali yang baru pertama kali melaksanakanya, dalam kondisi pandemic covid-19, keterbatasan sumber daya dan tidak berlatar teknologi informatika dan computer mencoba melaksankannya dengan penggabungan berbagai media sederhana mampu melaksanakan kegiatan virtual tour yang bisa diaplikasaikan oleh instansi lain yang memiliki keterbatasan sumber daya maupun teknologi dan dapat dikembangkan di kemudian hari.

\section{METODE PENELITIAN}

Metodologi yang digunakan dalam penelitian implementasi ini adalah metode perancangan. Stratetegi yang digunakan dalam merancang sebuah kegiatan ini menggunakan staretgi strategi linear (Sarwono, J \& Lubis 2007) yang menampilkan urutan logis tahapan perancangan yang sederhana dan sudah relativ sudah dipahami komponennya. Adapun tahap-tahap tersebut dapat dilihat pada gambar 1 .
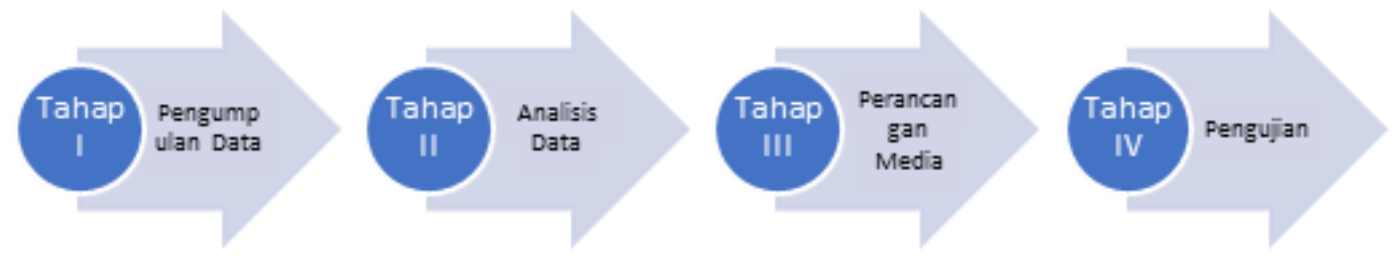

Gambar 1. Tahap Penelitian

[Sumber : Sarwono J \& Lubis, 2007] 
Sumber Data dalam penelitian ini adalah sumber data primer yang diambil langsung pada saat proses perancangan kegiatan untuk menghasilkan produk dihasilkan dan sumber data juga diambil dari sumber sekunder yaitu jurnal-jurnal terdahulu yang membahas mengenai penggunaan virtual tour dalam mengenalkan kampus baik di masa pandemi atau sebelum pandemi. Teknik Pengambilan data dalam penelitian ini adalah Teknik observasi partisipatif, dimana peneliti bertindak sebagai dosen pembimbing dalam kegiatan menciptakan virtual tour untuk memperkenalkan kampus Politeknik Pariwisata Bali. Seluruh proses kegiatan dan hasil observasi dicatat dan kemudian dibahas menggunakan data sekunder dan referensi yang didapatkan. Kemudian untuk mengetahui tanggapan peserta terhadap kegiatan ini ditentukan sampel penelitian dengan menggunakan metode slovin dengan tingkat kesalahan 10\% dan didapatkan jumlah sampel sebanyak 100 orang. Penelitian ini dilakukan di Kampus Politeknik Pariwisata Bali yang dulu Bernama Sekolah Tinggi Pariwisata Nusa Dua Bali Sebuah kampus di bawah naungan Kementerian Pariwisata dan Ekonomi Kreatif Republik Indonesia yang terletak di Jl. Dharmawangsa, Kampial, Nusa Dua, Kecamatan Kuta Selatan, Kabupaten Badung, Bali, Indonesia. Metode yang serupa digunakan oleh Achmad (2016) yang menggunakan diagaram aAlir dimana pada metode ini akan dipaparkan urutan Langkahlangkah yang diubuat secara sistematis untuk menyelesaikan penelitian. Sebagaimana dalam gambar 2 di bawah ini terdapat 3 langkah utama yang dilakukan yakni aAnalisa permasalahan, desain dan perancangan sistem, dan implementasi sistem.
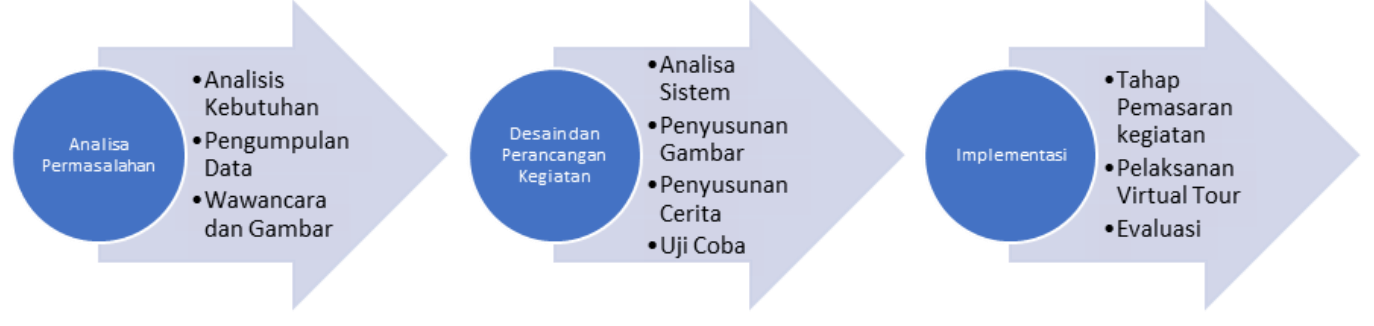

Gambar 2. Langkah utama

[Sumber: Diadaptasi dari Model Achmad 2016]

Adapun penjabaran tahapan diagram linear yang digunakan dalam penelitian ini adalah sebagai berikut:

1) Tahap Analisa Permasalahanhalan tahap ini merupakan proses melakukan observrasi analisa kebutuhan atau Analisa pasar yang dalam hal ini adalah Calon Mahasiswa Baru Poltekpar Bali Angkatan 2020 dan mengumpulkan data sejarah, fungssi masing-masing ruang, unit kerja yang ada dengan melakukan wawancara dengan pihak terkait dan mengumpulkan gambar dari file yang sudah ada maupun mengambil gambar baru.

2) Tahap Desain dan Perancangan Sistem tahap ini dilakukan pemilihan software dan aplikasi yang akan digunakan dalam virtual tour nanti yang sesuai dengan keadaan dan kebutuhan pasar, kemudian dilakukan penyusunan jadwal tur, gambar disusun berdasarkan jadwal tur, kemudian dirangkai dalam sebuah cerita yang akan dibawakan oleh pemandu wisata nantinya, dan melakukan uji coba dengan sistem dan jadwal tur yang sudah disusun dan mengetahui virtual tour yang dirancang sesuai dengan tujuan atau tidak

3) Tahap Implementasi tahap ini dimulai dengan melakukan pemasaran kegiatan virtual tour ini, kemudian tahap pelaksanaan pada waktu yang telah ditentukan dan melaksanakan evaluasi terhadap virtual tour yang sudah dilaksanakan untuk perbaikan kegiatan serupa di masa yang akan datang. 


\section{HASIL DAN PEMBAHASAN \\ 3.1 Tahap Analisa Permasalahan}

Kegiatan virtual ini merupakan sebuak project dari Tim Kecil Mahasiswa, dimana awalnya mahasiswa-mahasiswa ini seharusnya melaksanakan kegiatan Travel Lab yang bernama Escape Tour and Travel yang menjalankan kegiatan bisnis Tour and Travel konvensional, namun seiring datangnya Pandemi Covid-19 rencana tersbut harus segera beradaptasi dan mencari bentuk project yang lain tanpa melupakan cCapaian pPembelajaran yaitu menerapkan prinsip-prinsip manajemen dan kepemimpinan dalam sebuah project.

Untuk menentukan project baru maka dilakukan brainstorming kepada mahasiswa apa yang bisa dilakukan untuk menyelesaikan masalah walaupun dalam keadaan Pandemi, dari hasil brainstorming tersebut ditemukanlah beberapa masalah dan temuan sebagai berikut:

1) Kegiatan Virtual Tour merupakan salah satu kegiatan wisata yang sedang trend dan berjalan di masa pandemic Covid -19

2) Dalam waktu dekat akan diadakan kegiatan Pengenalan Sikap Dasar Profesi (PSDP 2020) atau kegiatan pengenalan kampus yang biasanya dilaksanakan secara offline harus dilaksanakan secara online, dan biasanya dalam kegiatan PSDP terdapat kegiatan Tour De Campus untuk mengenalkan lingkungan kampus yang merupakan lingkungan yang baru bagi calon mahasiswa baru.

3) Pengalaman kegiatan PSDP tahun sebelumnya mahasiswa hanya melihat sekilas suasana kampus tanpa tahu lebih detail beberapa bangunan, isi dan kegunaan bangunan.

4) Tim belum punya pengalaman untuk melaksankan dan membuat virtual tour dan tidak memiliki dasar keahlian pada bidang teknologi yang mumpuni namun memiliki kemampuan untuk membuat program wisata dan keahlian kepemanduan wisata
Dari hasil analisis masalah tersebut dilakukanlah pencarian referensi mengenai virtual tour idan menghubungi pihak-pihak terkait ijin pelaksanaan kegiatan dan yang akan terlibat seperti bagian akademik dikarenakan akan dikombinasikan sebagai kegiatan pengenalan kampus, Unit Hubungan Masyarakat untuk mendapatkan data dan informasi kampus sebagai destinasi atau produk yang akan dijelaskan, serta panitia kegiatan PSDP untuk mengintegrasikan acara.

\subsection{Tahap Desain dan Perancangan Sistem}

Desain awal dari kegiatan ini adalah menyusun Tour Itynerary atau Program Tur, selayaknya sebuah program tur nyata program tur kampus Politeknik Pariwisata Bali ini disusun berdasarkan cerita dan rute yang sebenarnya yang biasa dilalui oleh mahasiswa baru ketika program Tour De Campus, dengan menggunakan pendekatan penyusunan rute perjalanan yang disebut round dimana peserta tidak melewati jalur yang sama sebanyak dua kali. Dimulai dari Gerbang Kampus, Rektorat, Ruang Dosen, Aula, Gedung Pertemuan, Fafilitas Laboratorium, Kelas, Kantin, Koperasi, dan Fasilitas Olahraga dan dikahiri di tempat parkir. Di setiap tempat-tempat yang dikunjungi disusun cerita atau naskah yang akan dibawakan oleh pemandu wisata. Naskah atau cerita ini disusun berdasarkan Teknik interpretasi, dimana tim mendapatkan informasi sebanyak-banyaknya dari wawancara dengan berbagai pihak terkait mengenai tempat-tempat yang sebelumnya beberapa tim yang tidak ketahui juga, kemudian dikemas dalam sebuah cerita yang menarik tanpa meninggalkan esensi informasinya. Kemudian dalam penyusunan cerita atau naskah ini disusun tidak hanya menjelaskan nama dari Gedung namun juga menjelaskan fungsinya serta menunjukan gambar dalamnya serta beberapa cerita menarik seputar tempat-tempat tersebut sehingga calon mahasiswa baru memiliki 
pemahaman yang lebih mendalam mengenai calon kampus tempat mereka menuntut ilmu nantinya.

Kemudian tahap ini dilanjutkan dengan mendiskusikan teknologi dan platform apa yang akan digunakan untuk menjalankan virtual tour ini. Pladitama, R. (2015) menjelaskan bahwa virtual tour merupakan program simulasi yang menggabungkan teknologi fotografi dan teknologi informasi yang bertujuan untuk memberikan informasi ruang secara menyeluruh dan interaktif. Informasi ruang yang bisa diolah menjadi aplikasi ini meliputi indoor maupun outdoor. Virtual tour mampu memvisualisasikan kondisi suatu lokasi sehingga pengguna dapat melihat keadaan sekitar dan merasakan solaholah berada di lokasi yang sebenarnya. Ada beberapa elemen multimedia yang diganakan pada virtual tour seperti suara, narasi, video, dan pemandu virtual. Karena virtual tour bisa menggambarkan keadaan suatu lokasi maka virtual tour ini bisa dijadikan sebagai media untuk mengenalkan suatu tempat. Sementara pengertian serupa disampaikan Choiron, A. (2017) pengertian virtual tour sendiri adalah sebuah simulasi dari lokasi yang ada, biasanya terdiri dari rangkaian gambar diam. yang juga dapat ditambahkan elemen multimedia lain seperti efek suara, musik, narasi, dan teks. Berdasarkan pengertian di atas dan keterbatasan anggota tim akan biaya dan kemampuan penguasaan teknologi, maka tidak seperti penulis lain yang berasal dari latar belakang keilmuan teknologi informasi yang menggunakan teknologi e-panorama, google earth, video maupun foto 360 , maka tim memutuskan untuk menggunakan power point sebagai media visual, kemudian ditambahkan narasi dari pemandu wisata, dan video singkat di akhir tur sementara untuk platform streaming dipilih google meet disamping penampilan gambarnya lebih halus dikarenakan saat itu belum terdapat pemahaman tentang fitur upgrade dari zoom yang mampu menampung lebih banyak orang dengan durasi waktu yang lebih lama.

Selanjutnya proses berlanjut dengan pengumpulan data berupa foto-foto dari bagian Hubungan Masyarakat, ataupun pengambilan foto - foto baru oleh tim, kemudian disusun dalam halamanhalaman Power Point sesuai dengan cerita program tur yang sudah disusun. Berjalan bersamaan dibuatlah video yang memperkenalkan kampus secara umum dan singkat, yang merupakan rangkuman dari cerita program tur yang sudah dibuat. Setelah tersusun maka pemandu wisata mulai berlatih membawakan paket kegiatan virtual tur kampus Politeknik Pariwisata Bali. Karena sifatnya yang virtual dimana peserta dan pemandu tidak bertemu langsung, maka diperlukan Teknik khusus sehingga terdapat ikatan antara peserta dan pemandu sehingga seola-olah peserta ada ditempat yang diceritakan. Salah satu Teknik yang digunakan adalah Teknik story telling. Menurut Brooks (2014) menyampaikan bahwa salah satu kunci sukses pengembangan pariwisata adalah melalui storytelling, dimana tidak hanya mengekpose panorama untuk menarik turis, namun juga bagaimana turis dapat lebih mudah dalam mengingat cerita yang menarik dan menyentuh, sehingga mudah pula untuk disebarluaskan. Pemandu wisata kegiatan virtual tur ini pula menggunakan teknik itu pula, dengan mencari, dan menggali titik-titik paling menarik di kampus, memadukan dengan pengalaman, dan Bahasa yang sesuai dengan pasar dari kegiatan ini.

Langkah selanjutnya adalah melakukan uji coba, uji coba dilaksanakan sebanyak dua kali, dalam uji coba pertama yang dihadiri tim dan pembimbing, ditemukan kendala karena dilakukan ujicoba di kediaman tim yaitu jaringan dan sinyal, kemudian ditemukan beberapa informasi penting terlewatkan,foto yang tidak tepat, dan pembawaan pemandu wisata yang masih kaku, dan disarankan untuk diperbaiki dan pemandu wisata untuk berlatih 
Kembali. Uji coba kedua pelaksanaan sudah dilaksanakan di kampus yang memiliki jaringan yang lebih baik, fotofoto telah lengkap, cerita telah runut, dan pemandu lebih luwes dan di tahap kedua ini dihadirkan pula pihak-pihak terkait untuk memberikan masukan dan memvalidasi informasi yang disampaikan. Setelah dinyatakan valid dan sistem dapat berjalan dengan baik, kemudian disusun acara tambahan seperti pembukaan oleh MC, sambutan oleh pejabat terkait, dan penyusunan kuesioner. Setelahnya kegiatan siap untuk di implementasikan.

\subsection{Tahap Impelementasi}

Dalam tahap implementasi ini dimulai dengan melakukan pemasaran kepada target market dari virtual tour ini adalah calon mahasiswa baru Politeknik Pariwisata Bali. Untuk menjangkau calon mahasiswa baru Politeknik pariwisata Bali Tim berencana untuk mendapatkan e-mail dari seluruh calon mahasiswa baru, dan untuk mendapatkan e-mail tersebut Tim berkoordinasi dengan Kepala Bagian Administrasi Akademik, Kemahasiswaan, dan Kerjasama yang membidangi kegiatan penerimaan mahasiswa baru dengan bersurat kepada beliau. Setelah mendapat persetujuan beliau maka data e-mail dapat kami peroleh dari Unit Sumber Daya Informasi. Setelah itu dimulailah penyebaran e-mail secara masal kepada seluruh calon mahasiswa baru, sebelumnya darft e-mail dikonsultasikan kepada dosen pembimbing dari segi
Bahasa, setelah diperbaiki dan disetujui kemudian e-mail dikirimkan. Adapun Email tersebut berisikan tujuan kegiatan, tanggal dan waktu kegiatan, link pendaftaran google form, ajakan untuk mendaftar, dan kontak yang dapat dihubungi. Setelah calon peserta mengisi google form atau dengan kata lain melakukan pendaftaran, maka peserta akan mendapatkan e-mail balasan otomatis dari google form yang beriskan link Google Meet yang digunakan serta tata tertib selama mengikuti kegiatan nantinya.

Selain menggunakan e-mail promosi kegiatan dilakukan melalui media sosial, dalam hal ini sosial media yang digunakan adalah Instagram. Menurut survey Asosiasi Penyelenggara Jasa Internet (dalam Nurfian, 2019) ada tiga media sosial yang yang paling banyak dikunjungi masysarakat Indonesia di tahun 2018 yaitu facebook $(50,7 \%)$, Instagram $\quad(17,8 \%)$, dan youtube (15,1\%). Politeknik Pariwisata Bali memiliki beberapa akun media sosial diantaranya facebook, Instagram, twitter, dan youtube. Namun dari ke-empat akun sosial media resmi Polteknik Pariwisata Bali tersebut akun Instagram-nya lah yang paling banyak memilki pengikut dan paling aktif, oleh karena itu Tim memilih untuk melakukan promosinya melalui akun Instagram resmi Politeknik Pariwisata Bali @poltekparbali yang telah memiliki lebih dari 10 ribu pengikut. Adapun e-flyer yang digunakan adalah dalam gambar berikut:

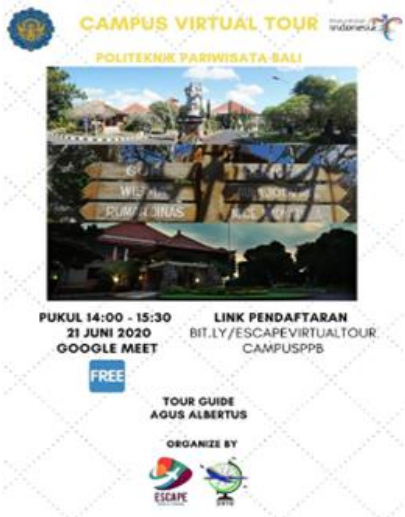

Gambar 3. e-flyer pelaksanaan Virtual Tour Kampus Politeknik Pariwisata Bali 


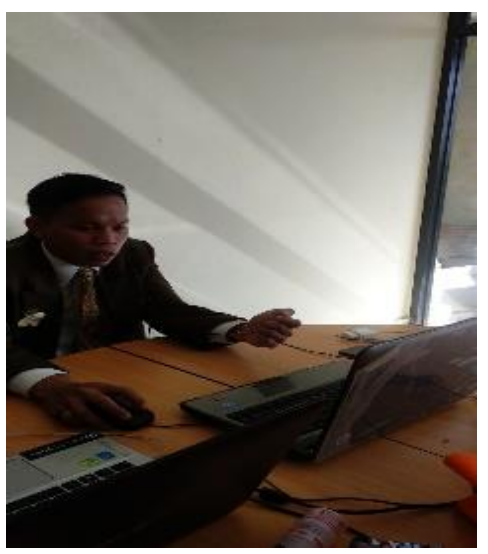

Gambar 4. Pemandu Wisata yang memandu kegiatan Virtual Tour

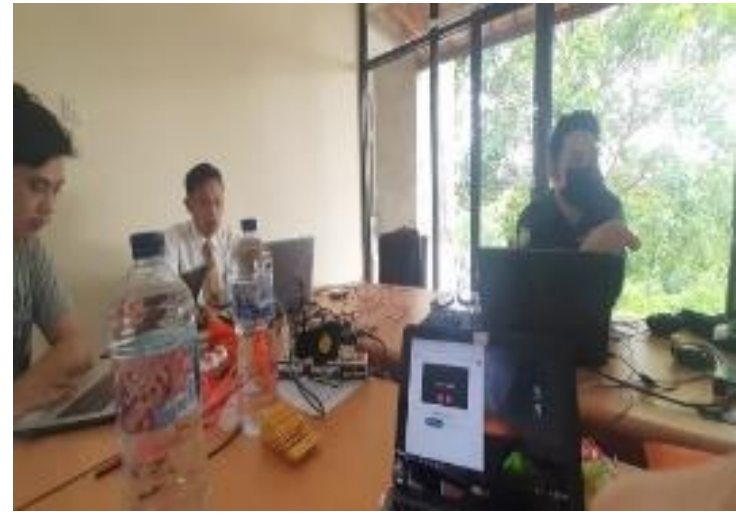

Gambar 5. Suasana Persiapan Tim dalam melaksanakan kegiatan Virtual Tour

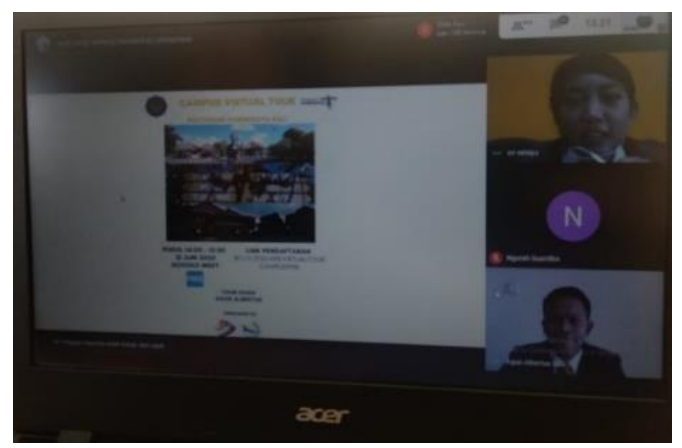

Gambar 6. Tangkapan Layar Kegiatan Virtual Tour

Kuesioner Evaluasi yang berhasil kembali dari 250 peserta adalah 108 dan hasilnya dapat dilihat dalam gambargambar berikut:

Bagaimana tanggapan Anda tentang pelaksanaan Virtual Tour ini secara keseluruhan?

108 tanggapan

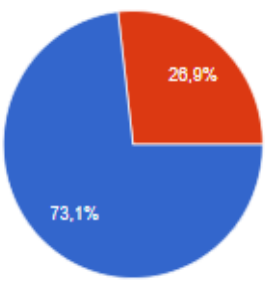

- Sangat Baik

- Baik

Cukup

- Kurang Baik

- Tidak Baik

Gambar 7. Tanggapan Peserta Terhadap Virtual Tour Secara Keseluruhan 
Bagaimana tanggapan Anda tentang Guide dalam memandu tur selama kegiatan berlangsung?

108 tanggapan

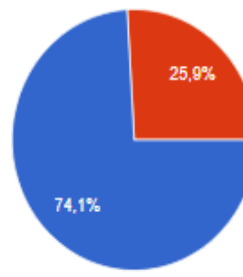

Sangat Baik

$$
\text { - Baik }
$$

Cukup

Kurang Baik

- Tidak Baik

Gambar 8. Tanggapan Peserta Terhadap Pemandu Wisata

Bagaimana tanggapan Anda tentang Guide dalam memandu tur selama kegiatan berlangsung?

108 tanggapan

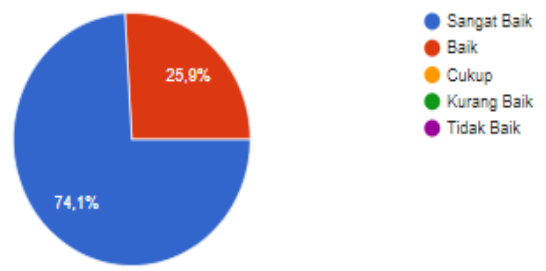

Gambar 9. Tanggapan Peserta Terhadap Pemandu Wisata

Bagaimana tanggapan Anda tentang pelayanan dari panitia mulai dari proses registrasi hingga kegiatan selesai?

108 tanggapan

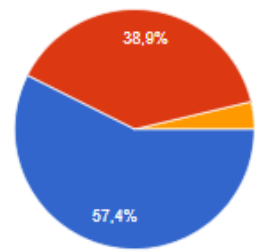

Sangat Baik

- Baik

Kurang Baik

- Tidak Baik

Gambar 10. Tanggapan Peserta Terhadap Panitia Penyelenggara

Apakah virtual tour kampus ini membantu / menambah informasi dan wawasan anda mengenai Kampus Politeknik Pariwisata Bali ?

108 tanggapan

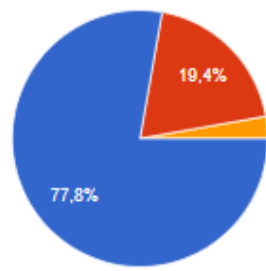

- Sangat Baik

Baik

- Cukup

- Kurang Baik

- Tidak Baik

Gambar 11. Tanggapan Kebermanfaatan kegiatan 


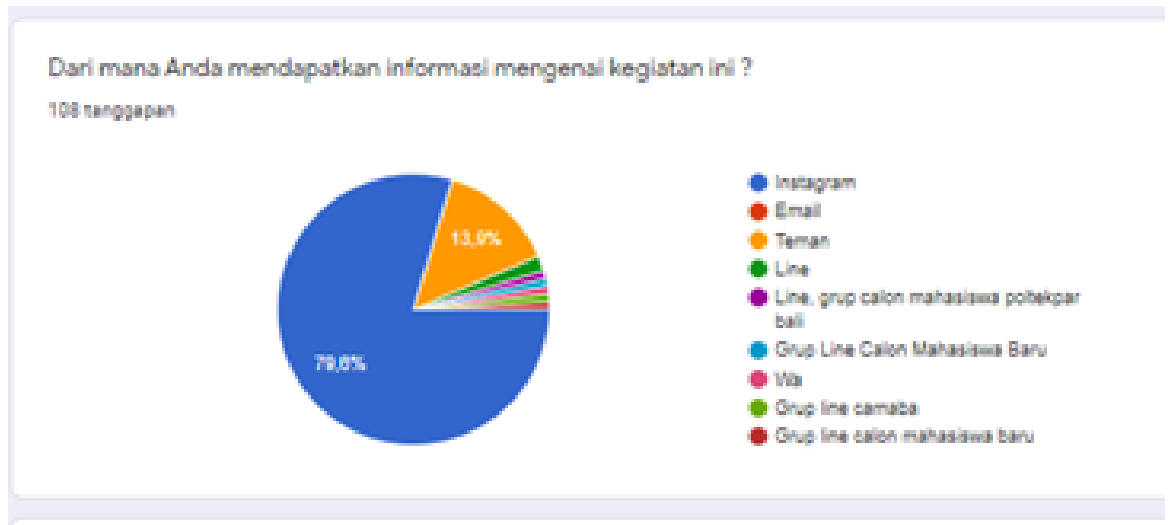

Gambar 12. Sumber Informasi Kegiatan

Dari gambar 5 dapat diketahui tanggapan peserta Sebagian besar atau 73,1 \% peserta memberikan tanggapan sangat baik dan 26,9\% memberikan tanggapan baik. Dari gambar 6 dapat diketahui lebih dari $50 \%$ atau $74,1 \%$ peserta merasa pelayanan pemandu wisata saat memandu jalanya virtual tour sangat baik dan 25,9\% menyatakan baik. Terkait dengan pelayanan dari panitia dapat dilihat dari gambar 7 diketahaui bahwa $54.7 \%$ peserta menyatakan bahwa layanan panitia mulai dari registrasi hingga pelaksanaan sangat baik, 38,9\% menyatakan baik dan sisanya menyatakan cukup. $77,8 \%$ dari peserta menyatakan bahwa mereka mendapatkan manfaat untuk menambah wawasan mengenai kampus Politeknik Pariwisata Bali dengan sangat baik, 19,4\% menyatakan baik, dan sisanya menyatakan cukup, hal ini dapat dilihat dalam gambar 8. Dari segi promosi dapat dilihat dalam gambar 9 bahwa kegiatan virtual ini diketahui 79,6 \% peserta dari Instagram resmi Politeknik Pariwisata Bali, 13,9 \% dari teman, dan sisanya dari saluran yang lain seperti e-mail, whatsapp, dan lain-lain.

Dari gambar-gambarpemaparan di atas dapat disimpulkan bahwa hasil dari kegiatan ini menunjukkan tanggapan yang positif dari peserta, walupun dijalankan dengan cara yang sederhana. Kemudian menelusuri dari pertanyaan terbuka yang diberikan ternyata ditemukan kendala dari kegiatan yaitu gambar video yang putus-putus, dan susah untuk masuk di awal karena jaringan yang cukup sibuk. Dari gambar di atas pula diketahui bahwa sumber informasi yang peserta dapatkan sebagian besar lewat Instagram yang mununjukan bahwa pilihan tim untuk memilih Instagram sebagai saluran promosi dari kegiatan ini.

\section{KESIMPULAN}

Dari hasil evaluasi terhadap kegiatan virtual tour pengenalan kampus Poltekpar Bali yang dilakukan oleh . Tim menunjukan hasil yang memuaskan, walaupun dilakukan dengan teknologi yang cukup sederhana yaitu Gambar, Power Point, Video, dan Narasi oleh pemandu wisata. Dalam masa pandemic Covid-19 kegiatan ini dapat dijadikan kegiatan pengganti Tour De Campus yang biasa dilakukan sebelumnya untuk mendapatkan gambaran gedung dan fungsi masing-masing gedung di Poltekpar Bali.

Kedepan jika pandemi masih berlangsung ataupun sudah selesai kegiatan ini masih bisa dilaksanakan sebagai sebuah sarana untuk memperkenalkan kampus namun dapat ditingkatkan dari segi penggunaan teknologinya dengan menggunakan platform premium sehingga mampu menampung lebih banyak calon mahasiswa dan jaringan lebih lancar, dan bisa menggunakan media foto/vido 360 atau e panorama sehingga gambar yang ditampilkan bisa lebih menarik ditambah teknik story telling oleh pemandu yang 
dapat memberikan gambaran jelas dan menarik tentang kampus. Implementasi sederhana ini pula dapat diduplikasi pelaksanaanya oleh sekolah/kampus/instusi lain yang memiliki keterbatasan pengetahuan dalam penggunaan teknologi.

\section{PERNYATAAN PENGHARGAAN}

Terima kasih penulis ucapkan kepada Manajemen Politeknik Pariwisata, Panitia PSDP yang memberikan ijin kegiatan ini berlangsung dan Mahasiswa MBP Sem 8 Angkatan 2016 kelas A sebagai pelaksana kegatan ini.

\section{DAFTAR PUSTAKA}

Abidah. A, Hidayatullah, H.N, Simamora, RM, Fehabutar, D, Mutakinati, L. 2020. The Impact of Covid -19 to Indonesian Education and It's Relation to the Philosophy of "Merdeka Belajar". Jurnal of Stuides in Philosophy of Science and Education.1(1), 38-49

Aji, Rizqon Halal Syah. 2020. Dampak Covid-19 pada Pendidikan di Indonesia: Sekolah, Keterampilan, dan Proses Pembelajaran. Jurnal Sosial dan Budaya Syar-i. 7 (5), 395-402. DOI: $10.15408 /$ sjsbs.v7i5.15314

Brooks, R. (2004) Presented on Wisconsin Governors Conference on Tourism, March 14-16Th

Budhiana, N. Gunung Agung Kembali Meletus Semburkan Asap Setinggi 2500 meter. Available from: https://regional.kompas.com/read/ 2017 /12/23/12052721/gunungagung-kembali-meletus-semburkanasap-setinggi -2500-meter. Date accessed: 08 June 2018.

Choiron, A. (2017). Aplikasi Virtual Tour Dinamis Pada Universitas Dr. Soetomo Surabaya Berbasis Web. Inform: Jurnal Ilmiah Bidang Teknologi Informasi dan Komunikasi, 2(1).

Falani, A.Z., Ramadan, H.A.S., Setiawan, E. 2016. Implementasu Sistem Virtual Tour Berbasis E-panorma untuk Pengenalan Kampus Universitas
Narotama Surabaya. Jurnal Insand Comtech. 1(1) Hal 9-16

Kusmayadi. 2004. Statistika Pariwisata Deskriptif (Descriptive Tourism Statistic). Jakarta: PT Gramedia Pustaka Utama.

Nurfian S, Febriani. (2020). Preferensi Generasi Milenial pada Tingkat Pengetahuan Ca;on Legistlatif. Jurnal Of Communication. 4(1), 89-107

Pandu, W. (2016). Aplikasi Pengenalan Kampus Berbasis Web dengan menggunakan Teknologi Virtual Tour (Studi Kasus Kampus III Univeristas Sanata Dharma. Skrispsi Program Studi Teknik Informatika, Fakultas Sains dan Teknilogi Univeristas Sanata Dharma Yogyakarta.

Pladitama, R. (2015). Virtual Tour Pada

Situs Trowulan Mojokerto Menggunakan Panorama 3600 (Doctoral dissertation, Institut Teknologi Sepuluh Nopember)

Rizal, B. N. B. \& Wenas, M. B. (2020). Perancangan Virtual Tour Kampus I UKSW Sebagai Media Informasi Mahasiswa Baru.Junrl Andharupa 4(1). Hal 51-65

Sarwono, J \& Lubis H. (2007). Metode Riset Untuk Desain Komunikasi Visual. Yogyakarta: Penerbit: Andi

Sugiarto, E. (2004). Operasional Kantor Hotel (Hotel Front Office Operationals). Jakarta: PT Gramedia Pustaka Utama.

Sugiyono. (2011). Metode Penelitian Administrasi (Administrative Research Method). Bandung: Alfabeta.

UNESCO.2020. Education Emergencies. Maret 28, 2020. from https://en.unesco.org/themes/educat ion-emergencies/coronavirus-schoolclosures

Yoeti. (2003). Tours and Travel Marketing. Jakarta: Pradnya Paramita.

Yulianingsih, T. (2018). Gunung Raung Kembali Meletus, 3 Bandara Kembali Ditutup Lagi. available from https://www.liputan6.com/news/rea d/ 2277164 /gunung-raung-kembalimeletus-3-bandara-ditutup-lagi. Date accessed: 08 June 2018 